\title{
THE IMPROVEMENT OF KANSEI ENGINEERING BY USING THE REPERTORY GRID TECHNIQUE
}

\author{
Falk Steinberg, Philipp Tursch, Ralf Woll \\ Chair of Quality Management, Brandenburg University of Technology Cottbus, Germany \\ Corresponding author: \\ Philipp Tursch \\ Brandenburg University of Technology Cottbus-Senftenberg \\ Chair of Quality Management \\ Siemens-Halske-Ring 14, 03046 Cottbus, Germany \\ phone: (+49) 355-69-3947 \\ e-mail: philipp.tursch@b-tu.de
}

Received: 7 April 2015

Accepted: 26 June 2015

\begin{abstract}
A customer-oriented approach to product development with particular consideration of emotions is represented by Kansei Engineering. Developed by Mitsuo Nagamachi, Kansei Engineering is characterized by the possibility to capture customer perceptions and to translate them into product features. In order to assess these perceptions, a semantic space is generated. For this purpose it is necessary to identify Kansei words that are gathered up through research in marketing concepts, scientific journals and service reports. This procedure though displays the disadvantage of not being able to identify all emotions referring to the investigated product.

One way to improve the identification of Kansei words is Repertory Grid. The Repertory Grid technique makes it possible to gather unaltered perceptions through in-depth interviews from the direct interaction with customers. Thus, the interview phase of the Repertory Grid technique offers an improved approach to identify of Kansei words.
\end{abstract}

KEYWORDS

Kansei Engineering, Repertory Grid, emotion, product development.

\section{Introduction}

To be successful in today's global market, changes in product development lead to manufacturers increasingly having to deal with the development of their products' performance in terms of function, design, quality and cost. Products need to have unique selling points that induce customers from a wide selection of consumer goods to buy a certain product [1]. To create these unique selling points it is necessary that the product is sighted holistically in the development process. This holistic approach includes requirements such as compliance with certain technical specifications or the availability of certain features, alongside increasingly important "softer" factors determined by design, haptic, or brand image.

The collection and analysis of these softer factors, however, implicate other challenges than the compliance with technical tolerances. The perceptions of customers have to be detected and transferred to the requirements in order to be considered later on in the product. These perceptions are often too difficult to be captured in numbers and characteristics. Therefore it is necessary to define a systematic approach to implement these factors in product development and use [2].

This paper aims at introducing the Kansei engineering method, identifying potential for improvement such as clamping of the semantic space, and elucidating an approach for an improved use of the Repertory Grid technique. A system will be developed that makes it possible to capture and analyze the multiple factors that impinge upon the involvement of emotions.

\section{Presentation of the Kansei engineering with special emphasis \\ on the semantic space}

Kansei is a multi-faceted concept that features different aspects depending on the definition [3, 4]. 
The definition of Kansei researcher Mitsuo Nagamchi is:

"Kansei refers to the state of mind where knowledge, emotion, and passion are harmonized; people with rich Kansei are full of emotion and passion, and able to react adaptively and sensitively to anything. "

Kansei Engineering's focus lies on the perception of an object and the thereby evoked responses [1, 5]. It is a method that combines feelings and emotions with the product development. This combination is then translated into product features.

Mitsuo Nagamachi began the research on Kansei Engineering in the 1970 s. The main aim was to feature the needs and demands of customers in terms of emotional aspects [5]. With the help of diverse advancements, the Kansei engineering system could be transferred to a variety of industries and applications [5].

The current developments and the number of publications in the field of Kansei engineering show that dealing with emotions in the product development process undergoes a strongly increasing significance $[1,3-5]$.

\section{Product development based on emotions}

The systematic collection and analysis of feelings and emotions renders new insights by being combined with psychological, ergonomic, medical or scientific methods which then can be translated into product specifications $[1,5,6]$.

Regarding emotional demands in the product development process provides the developing companies and organizations with added value to meet the needs of customers, to establish unique selling points of their product on the market and to create distinguishing features. In many cases, emotions are rarely considered within the product development process.

Kansei Engineering supplies their companies and organizations with a methodology that adopts a procedural thought and prescribes a clearly structured approach to product development based on emotions. Additionally, Kansai Engineering can also be integrated into the already existing product development process. Nagamachi [5] phrases the required process steps as follows:

1. Grasp the consumers Kansei in the specific product domain [...] using psychological or psychophysiological measurements.

2. Analyze the Kansei data by statistical, medical, or engineering methods in order to clarify the Kansei structure.

3. Interpret the analyzed data and transfer the data to the new product domain.
4. Finally, design a new Kansei product. Without numeration.

\section{The Kansei system:}

\section{the way to a Kansei product}

A general approach is used to introduce Kansei Engineering by the scheme shown in Fig. 1.

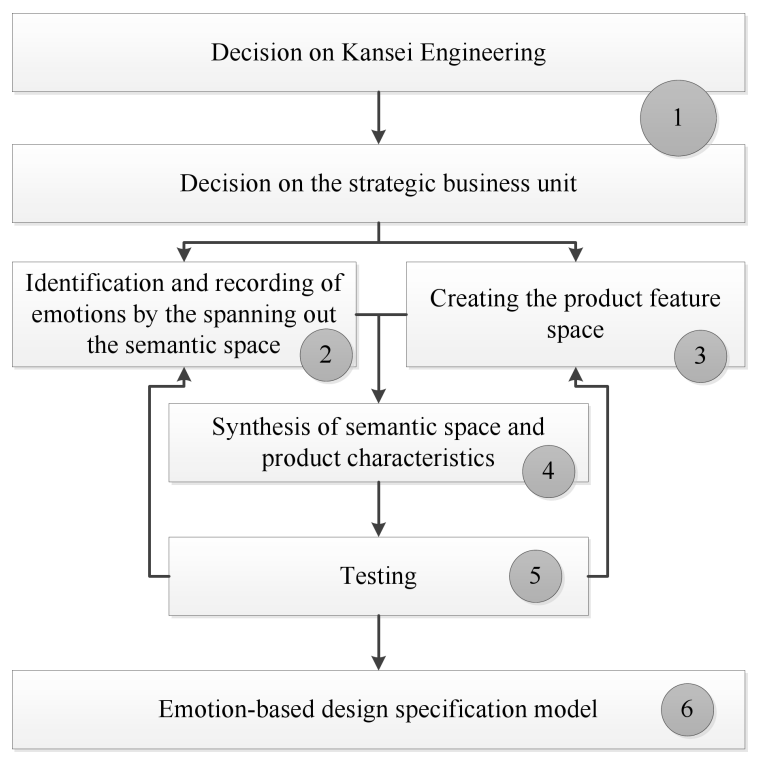

Fig. 1. The way to a Kansei product.

(1) Decision on Kansei Engineering and the strategic business unit: The strategic product field for the use of Kansei Engineering can be both new product development and product improvement. In product improvement, Kansei Engineering can be applied to the component level as well as the total product.

(2) Identification and recording of emotions by the spanning out the semantic space: To identify emotions, Kansei engineering especially uses the Kansei words [7]. By using these words, the investigated products are delineated emotionally and thus a semantic space is spanned. Traditional sources for the identification of Kansei words can be e.g. marketing reports, customer or employee feedback or depictions from the product requirement document and functional specification document. With the help of Kansei words the emotional level of an object can be conceived. These words form a basis for subsequent analysis.

The traditional collection of Kansei words usually implies the determination of a large number of terms which are included in the synthesis. Nagamachi stressed that a greater amount of Kansai words should be maintained. Other studies, however, come to the conclusion that a large number of con- 
ceptual pairs and their associated assessment represent a major burden for the subject group. Ordinarily, about 20 Kansei conceptual pairs are utilized [8]. The reduction of the Kansei words to a few always poses the risk of information loss as important emotional aspects may be lost.

Furthermore, the elicitation of Kansei words from marketing reports, customer or employee feedback, or depictions from the product requirement document and functional specification document are not always complete. Important emotional aspects may be partially disregarded since the direct interaction with the customer is missing. The customers' sensory input is not captured by the traditional collection of Kansei words.

Another disadvantage of the traditional approach is the lack of references of Kansei words. It is not always clear which component of the product a particular customer is referring to. Engineers therefore often have to try to interpret the customer statements correctly. In addition, engineers have to combine and ascertain the connection between the constructive, creative and functional reciprocity of the product and the emotions. Only on this concatenation enables the transfer from results into product specifications.

After the identification of the Kansei words, usually a Kansei survey employing a questionnaire is conducted. Therefore, Kansei words with different variable attributions are rated in relation to the object under examination $[9,10]$. Different scales can be used. In the subject group's assessment the Kansei conceptual pairs are contrasted and their markedness is evaluated.

(3) Creating the product feature space: Here, the collection of product features in existing products but also in designs, expert interviews, prototypes and new combinations have priority. Additionally, it has to be decided which properties are relevant to the soon to be developed product [8].

(4) Synthesis of semantic space and product characteristics: The synthesis is the core of Kansei engineering where the semantic space is connected with the product characteristic space. Product characteristics are identified that express emotions via Kansai words [4]. For the analysis of data mainly the principal component analysis is performed. This aims at reducing the large amount of data $[11,12]$. An additional evaluation method is the cluster analysis aiming at identifying similar structures in large databases. The determined clusters and principal components render the deduction of insights possible that allow the drawing of inferences about the structural properties of the product $[12,13]$.
(5) Testing: After the synthesis, the validity with respect to semantic space and product feature space is investigated. It is examined which Kansei words and product features will or won't be included in the further investigation or study [8].

(6) Emotion-based design specification model: With the help of the above presented steps acquired findings need to be incorporated into the product development. Recommendations will be made to reflect the emotional needs of the customer as closely as possible in a first draft of the product.

The illustrated steps of the process show that Kansei Engineering provides a clearly structured approach for the integration of emotional factors in the product development. Nevertheless, the approach reveals weak spots particularly with regard to the Kansei words. In determining Kansei words from traditional channels it is not ensured that all customerrelevant terms are recorded. Furthermore, it is unclear how many conceptual pairs that need to be evaluated are reasonable for the subject group. At too low a number the probability of a loss of information is large, whilst with of a great amount pairs the subject group might be overstrained and a low quality of results can be expected. Another disadvantage of the traditional method of determining Kansei words is the lack of references. An important point is the basic dealing with and the interpretation of emotions and feelings. Emotions and feelings are complex patterns which are permanently re-evaluated due to experience. They are not necessarily steady and differ from person to person [14]. Emotions are characterized by strong subjectivity. The risks associated with emotions do not only reside in the interviewee but the main responsibility lies in the transformation of the subjective data into objective specifications whilst the evaluation. The analysts generally act subjectively and therefore the reliability of the results is suffering [14]. The analyzing person interprets the subject group's mental and physical behavior. This interpretation often only reflects the subjective interpretation of a person. To remedy these weaknesses, the Chair of Quality Management of the BTU Cottbus developed a modified Repertory Grid technique [15].

\section{General procedure of the Repertory Grid technique to derive construct systems}

A complete explanation of the Repertory Grid technique can be found in the following references. Within the meaning of Kansei Engineering, it is sufficient to know the approaches. The Repertory Grid technique is a versatile and semi-structured in-depth 
interview. It was developed in 1955 by George A. Kelly in the fields of Personal Construct Psychology and identifies personal constructs of patients [16-18].

The central terms of Kelly's theory are the Personal Constructs and the Element [19]. Together the elements and constructs constitute the basis of the realized, structured world of the individual [19]. Elements are assessable things, persons, objects, situations as well as products or services to the respondent. What is considered an element and how large the number of elements to be considered is, is at the discretion of the examiner or is dependent from the problem [20]. Constructs are the result of the evaluation of the studied elements. They represent the subjective viewpoint of a person towards the elements and do not always refer to observable characteristics [17, 19]. Construct and contrast jointly constitute the construct system. The obtained construct systems consist of construct and contrast pole [19]. The respondent of the subject group is presented with the possibility of polarization after the designation of the constructs, i.e. he has to decide whether he rather prefers construct or contrast pole [21].

The following Table 1 provides a summary of the most important terms, which should help to understand the following investigation.

Table 1

Summary of the most important term.

\begin{tabular}{l|l|l}
\hline Component & Explanation & Reference \\
\hline Element & $\begin{array}{l}\text { Elements of the respon- } \\
\text { dents are assessable } \\
\text { things, persons, objects, } \\
\text { situations, etc. }\end{array}$ & $\begin{array}{l}\text { Motorcycle Hel- } \\
\text { met }\end{array}$ \\
\hline Triad & $\begin{array}{l}\text { three elements are com- } \\
\text { pared to each other with } \\
\text { the guideline of condens- } \\
\text { ing two elements due to } \\
\text { one characteristic }\end{array}$ & $\begin{array}{l}\text { presented Hel- } \\
\text { mets }\end{array}$ \\
\hline Construct & $\begin{array}{l}\text { Constructs are evalua- } \\
\text { tions of elements and re- } \\
\text { lated to characteristics. }\end{array}$ & $\begin{array}{l}\text { user-unfriendly } \\
\text { closure vs. easy } \\
\text { to use closure }\end{array}$ \\
\hline Laddering & $\begin{array}{l}\text { Targeted questions of } \\
\text { the respondent in rela- } \\
\text { tion to the triad to take } \\
\text { the respondent to a dif- } \\
\text { ferent level. }\end{array}$ & $\begin{array}{l}\text { What does that } \\
\text { mean?" do you? you }\end{array}$ \\
\hline Dichotomy & Contrast constructs & narrow - wide \\
\hline
\end{tabular}

The Repertory Grid technique is used for evaluation and utilization of associations of subjects determined by the analysis of the ascertained construct systems $[19,20]$. This provides the investigator with an insight in how the subject describes and assesses from his own perspective.

Further background to the Repertory Grid technique can be found in [15] and [22]. In addition, other examples there are mentioned, which can be transformed into the Kansei Engineering.

\section{Support for spanning the semantic space by Repertory Grid on the example of motorcycle helmets}

The following section describes the Repertory Grid technique using the example of motorcycle flipup helmets. The objects of study are eight motorcycle flip-up helmets which were tested for their perception by 24 test persons.

According to Griffin/Hauser [23] there are 20 to 30 interviews in a relatively homogeneous customer segment necessary to identify more than $90 \%$ of customer requirements. Assuming this to be regarded in relation to the scope of the qualitative approaches. Therefore is also assumed that the present 24 interviews, much of the relevant emotions are covered.

The Repertory Grid technique is only performed up until Kansei words are identified since this is the focus of this study. It shall be shown which contribution the Repertory Grid technique can make to capture and evaluate customer perceptions.

For each customer, there are individual perception characteristics that are heavily dependent on emotions and therefore can be identified using the Repertory Grid technique [24]. The study participants were offered a free choice of five out of eight helmets. These formed the basis for the interview. The participants' task was to assess the ten possible triads which resulted from the five chosen helmets. Table 2 summarizes all conditions and results of the investigation.

Table 2

Summary of the Repertory Grid workshop.

\begin{tabular}{l|l}
\hline Product & Motorcycle Helmets \\
\hline Number of Interviewer & 5 \\
\hline Number of test persons & 24 (4 female, 20 male) \\
\hline Age Range & $22-29$ \\
\hline Number of triads & 10 \\
\hline Elicit construct systems & 240 \\
\hline Period of time & 5 hours \\
\hline
\end{tabular}

The study participants were shown all possible triads from the five flip-up helmets. In order to avoid multiple entries for recurring pairs the succession of the triads had been fixed beforehand. Another possibility in this context is random selection which was not considered here.

In a first step the test persons were given the opportunity to familiarize with the elements. After- 
wards the study participant and the interviewer created the so-called construct systems of a Repertory Grid. An example of a construct system is e.g. "boring vs. innovative" or "difficult closure vs. simple closure". The construct systems are to be equal with the Kansei words since emotions evoked by the motorcycle helmet are expressed in form of construct systems. The participants were divided into ten consecutive triads in which they should compare the different helmets and were asked about their personal constructs. To develop these constructs the following question has always been asked: "Which two of the three flip-up helmets of the triad differ referring to which particular characteristic?". The results were documented by the interviewer. At the beginning of the interview, constructs were quickly made by the subject. With increasing progress of the interview, it was becoming progressively difficult for the respondents to nominate new construct systems, especially since duplications were supposed to be avoided. At this point of the interview the laddering used. This is the transfer of the participant to a higher or deeper psychological level. The use of Laddering requires intensive preparation on the side of the interviewer to help the respondent in construction building. In case of double occurrence of statements such as: "narrow" or "wide" the subject was transferred to a higher level with the help of specific questions like: "What do you mean?" or "What does that mean to you?".

After all ten construct systems were gathered, the study participant was asked about the polarization of the constructs. The aim was to identify the personal preference of the respondent. If the construct system consisted for example of "round" and "square", the participant would be asked if he preferred a round or a more square design.

\section{Evaluation of the examination}

When evaluating a Repertory Grid it is possible to analyze each interview individually to identify characteristics and differences in the study participants. In most cases, all of the individual Grids are combined and considered as a master Grid [25].

First, the 240 collected construct systems are allocated to 14 helmet components. These represent the reference. Some examples of references in a motorcycle helmet are: visor, helmet shell, chin strap, switch of the opening mechanism, sun shield, etc. A rough overview of the product under investigation is compiled with the aim of addressable references. With the help of these references, construct systems and Kansei words can be clearly assigned. This procedure prevents misunderstandings, i.e. that the study participant understands the conceptual pair differently from the analyst.

The analysis of a Repertory Grid interview is much more complex and extensive than shown here because methods such as principal component analysis may be used. The determined Kansei words can now be connected with the product attribute space via synthesis. To determine the Kansei words in the presented approach, however, offers a way to identify perceptually determining characteristics which are partly caused by emotions. The Repertory Grid technique methodically constitutes an approach for the identification of Kansei words.

\section{Summary}

In order to use the methodology of Kansei engineering successfully, it is necessary to capture the perceptions of customers regarding the products. Only if the detection of perceptions and the associated emotions works correctly and completely, products can be developed that meet customer requirements and are perceived by customers as such.

This paper has shown that the Repertory Grid technique provides an approach to identify and evaluate Kansei words. Through in-depth interviews, conducted as part of a Repertory Grid, external study participants compare products from different vendors and express their opinions about differences and similarities. Special consideration is given to emotions because the respondents do not test the products but only evaluate them in terms of product appearance or perception. To identify Kansei words only a portion of the entire Repertory Grid technique is needed. The determined Kansei words are methodically derived and express the perceptions and emotions of customers. They are therefore more meaningful and realistic than Kansei words coming from marketing concepts, journals or service reports.

The Repertory Grid technique contributes to the support of the identification of Kansei words. With this procedure, and the use of Repertory Grid technique, the Kansei engineering can be supported. The spanning of the semantic space can be extended by another tool. This results in a greater variety of sources of Kansei words. The presented approach improves the quality of the semantic space and consequently the quality of the derived product drafts as well as designs.

\section{References}

[1] Nagamachi M., Lokman A.M., Innovations of Kansei Engineering, Boca Raton, CRC Press, 2011. 
[2] Norman D.A., Technology First, Needs last: the Research-Product Gulf, Interactions, March/April, 38-42, 2010

[3] Nagamachi M., Perspectives and the new trend of Kansei/affective engineering, The TQM Journal, 20 (4), 290-298, 2008

[4] Schütte S., Engineering Emotional Values in Product Design (Dissertation, Linköpings universitet, Linköping, 2005.

[5] Nagamachi M., Kansei/Affective Engineering and History of Kansei/Affective Engineering in the World, In M. Nagamachi (Hrsg.), Kansei/Affective Engineering, 1-12, Boca Raton, CRC Press, 2011.

[6] Schütte S., Eklund J., Axelsson J., Nagamachi M., Concepts, methods and tools in Kansei engineering, Theoretical Issues in Ergonomics Science, 5 (3), 214-231, 2004.

[7] Barnes C., Childs T., Lillford S., Kansei/Affective Engineering for the European Fast-Moving Consumer Goods Industry, In M. Nagamachi (Hrsg.), Kansei/Affective Engineering, 253-274, Boca Raton, CRC Press, 2011.

[8] Lindberg A., First Impressions Last - A Kansei Engineering Study on Laminate Flooring at Pergo, Linköping, 2004.

[9] Huang M.-S., Tsai H.-C., Huang T.-H., Applying Kansei engineering to industrial machinery trade show booth design, International Journal of Industrial Ergonomics, 41 (1), 72-78, 2004.

[10] Ishihara S., Ishihara K., Nagamachi M., Sano M., Fujiwara Y., Naito M., Ozaki K., Developments of Home Electric Appliances with Kansei Ergonomics: SANYO cases: Kansei and Kinematic considerations on Washer-Dryer and Electric Shaver, 11th QMOD Conference, Quality Management and Organizational Development, Attaining Sustainability From Organizational Excellence to Sustainable Excellence, Helsingborg, 2008.

[11] Brachinger H.W., Ost F., Modelle mit latenten Variablen: Faktorenanalyse, Latent-StructureAnalyse und LISREL-Analyse, In L. Fahrmeir, W. Brachinger, A. Hamerle, G. Tutz (Hrsg.), Multivariate Statistische Verfahren (2. Aufl.), Berlin/New York, Walter de Gruyter, 1996.

[12] Nagamachi M., Statistical Analysis for Kansei/Affective Engineering, In M. Nagamachi (Hrsg.), Kansei/Affective Engineering, 53-140, Boca Raton, CRC Press, 2011.

[13] Bacher J., Pöge A., Wenzig K., Clusteranalyse. Anwendungsorientierte Einführung in Klassifikationsverfahren (3. Aufl.), München, Oldenbourg Wissenschaftsverlag, 2010.
[14] Zimbardo P.G., Gerrig R.J., Psychologie (18. Aufl.), München, Pearson Deutschland GmbH, 2008.

[15] Tursch P., Steinberg F., Woll R., A first step towards engineer-oriented adaption of the Repertory Grid Technique, Total Quality Management \& Business Excellence, 25, 7-8, 734-749, 2014.

[16] Kelly G.A., The psychology of personal constructs (1, 2), Norton, New York, 1955.

[17] Fromm M., Beiträge zur Psychologie der persönlichen Konstrukte, Waxmann, Münster u.a., 1999.

[18] Curtis A.M., Wells T.M., Higbee T., Lowry P.B., An Overview and Tutorial of the Repertory Grid Technique in Information Systems Research, Communications of the Association for Information Systems (CAIS), 23 (3), 37-62, 2008.

[19] Rosenberger M., Freitag M., Repertory Grid, In Kühl S., Strodtholz P., Taffertshofer A. (Hrsg.), Handbuch Methoden der Organisationsforschung, Quantitative und Qualitative Methoden, 477-497 VS Verlag für Sozialwissenschaften, Wiesbaden, 2009 .

[20] Scheer J.W., Planung und Durchführung von Repertory Grid-Untersuchungen, In Scheer J.W., Catina A. (Hrsg.), Einführung in die Repertory GridTechnik, Grundlagen und Methoden (Bd. 1), 24-40, Huber, München, 1993.

[21] Tan F.B., Hunter M.G., The Repertory Grid technique: A method for the study of cognition in Information Systems, In MIS Quartely, 26 (1), 39-57, 2002.

[22] Tursch P., Baumert K., Woll R., Repertory Grid - Potential for Requirements Management in the Quality Function Deployment - an Example of the German Smartphone Market, Transactions of the 24th Symposium on QFD, St. Augustine (USA), 2012 .

[23] Griffin A., Hauser J.R., The Voice of the Customer, Marketing Science, 12 (1), 1-27, 1993.

[24] Steinberg F., Woll R., Damit der Ersteindruck stimmt - Wie wahrnehmungsbestimmende Merkmale greifbar werden, Qualität- und Zuverlässigkeit, 57 (12), 54-55, 2012.

[25] Fransella F., Bell R., Bannister D., A Manual for Repertory Grid Technique, 2. Auflage, Wiley, Chichester, 2004.

[26] Kamiske G.F., Brauer J.-P., Qualitätsmanagement von $A$ bis $Z$. Wichtige Begriffe des Qualitätsmanagements und ihre Bedeutung, 7. Auflage, München, Hanser, 2011. 